\title{
Human Resources in Industrial Tourism
}

\author{
Barbara Pavlakovič \\ Faculty of Tourism, University of Maribor, Slovenia \\ barbara.pavlakovic@um.si
}

Eva Jereb

Faculty of Organizational Sciences, University of Maribor, Slovenia

eva.jereb@um.si

Industrial tourism, as a specific type of tourism, emerged over a century ago but was not studied widely until recently. However, most of the current research is focused either on heritage industrial tourism or on several aspects, such as visitor characteristics, relation to the local economy, and similar. This paper attempts to highlight the human resources aspect of industrial tourism in different organisations. Our primary research methods were observation with participation (joining factory tours) and semi-structured interviews with company representatives. We define various existing categories of industrial tourism human resources models of organisations that carry out industrial tourism, the necessary competences for the workplace, and the methods of educating industrial tourism employees. Based on the gathered results, we propose some guidelines for companies to follow in forming their products of industrial tourism.

Keywords: HR, competence, education, industrial tourism, HR model

(cc)BY-SA https://doi.org/10.26493/2335-4194.13.51-65

\section{Introduction}

Human resources are the basis of an organisation's activities, since the organisation does not exist without them. One of the most critical aspects of HR management is the concern for the development of employee knowledge, that is, the implementation of education and training. With this, the organisation ensures continuous development and progress and maintains and strengthens its value on the market (Armstrong, 2012; Bratton \& Gold, 2012). Education and training take place in various forms and are adjusted to the position of an employee within the organisation, to his/her previous knowledge and abilities. Here we encounter another essential aspect of $\mathrm{H} \mathrm{R}$ management. Employees must have the appropriate competences to perform the work efficiently and effectively (Svetlik, 2005). The task of the supervisor is to recognise the capabilities of employees and, firstly, to place them in a specific po- sition, and then to ensure that these competences are further upgraded in the process of education or training.

In this research, we focused on the study of the necessary competences and the practice of developing the knowledge of employees in companies that carry out industrial tourism. Industrial tourism, as a particular tourist product, is distinct from the production process itself and, as such, does not provide added value in the creation of a factory's primary product. However, with a thoughtful strategy, the product of industrial tourism can become a powerful marketing tool and, at a very developed stage, it can be a new product of an organisation that can be marketed independently. Employees involved in the implementation of industrial tourism become the first representative of the organisation, before visitors and potential buyers of the company's primary product. Therefore, they must be 
properly selected, have the appropriate competences, and take care of the development of their knowledge.

The purpose of the research was to present a human resources model for industrial tourism. To achieve this purpose, several research objectives were developed. First, we wanted to define the types of employees that carry out industrial tourism. We were interested in whether there are any differences between the companies engaged in industrial tourism. The second objective was to identify competences that are necessary for the implementation of industrial tourism. The third objective was to outline the modes of the education of industrial tourism employees.' In the research, we examined how Slovenian companies carry out industrial tourism and how they take care of the personnel involved in this product.

\section{Literature Review}

Industrial Tourism

The concept of industrial tourism can be defined as a type of tourism that includes visits to operating companies and industrial heritage sites. Visitors can taste edible products, view production processes, try out interactive applications, and experience historical insights into the company (Otgaar et al., 2010; Rodríguez-Zulaica, 2017). According to Ifko (2010) and Vargas-Sánchez et al. (2014), industrial tourism can be considered to be a viewing of industrial heritage or operating processes, although it is not necessarily considered as a type of tourism but as a marketing activity (Chow et al., 2016; Otgaar, 2012). There is evidence that tourists have been visiting companies for over a hundred years (Frew, 200o; Page \& Connell, 2014). For example, in France, they visited vineyards and chocolate factories, in the United States whiskey distilleries, and elsewhere in the world anything from tobacco factories to mines and stock exchanges. In this regard, industrial tourism is perceived as a tourist attraction; such attractions (Edelheim, 2015) are a strong motivator for travel and can be divided into several groups, including cultural attractions, natural sights, events, recreation and entertainment; they can also be categorised as being natural or manmade (Goeldner \& Ritchie, 2003; Holloway \& Humphreys, 2016). Industrial tourism can be placed in the category of cultural sites and is a form of cultural tourism (Yamashita, 2014). Cultural tourism places particular emphasis on education and entertainment components (Frank Orel \& Medarić, 2018) and industrial tourism offers precisely that: education about industry and entertainment while observing production processes or participating in interactive displays.

As a form of cultural tourism, industrial tourism is an important factor in European countries, especially for those with long industrial traditions, such as Great Britain, Spain or Germany. However, more and more central and east European countries are recognising the benefits of industrial tourism, since they also built their economy on different industries and are nowadays still strongly dependent on them. For example, the Czech Republic and its town Ostrava are building their tourism on industrial tourism (Kajzar \& Václavínková, 2016). However, other countries with rich industrial heritage still lack further industrial tourism development; for example, Hungary only has heritage industrial tourism (Boros et al., 2013), and Croatia has some initiatives about power plant and mining visits (Gržinić et al., 2009). Industrial tourism and its offer of factory tours and visits to industrial heritage sites is also present in Slovenia. However, the local scientific research is primarily focused on industrial heritage (e.g., mines) (Ifko, 2010).

Meanwhile, industrial tourism can be an appropriate alternative to the existing tourism services, since in Slovenia and abroad there are many operating plants, well-organised companies with innovative business processes, and interesting service activities that tourists would visit. Thus, industrial tourism becomes a critical socio-economic phenomenon for which interest is growing. As stated by Xie (2006) and MacCannell (2013), one of the reasons for the popularity of industrial tourism is that society is in the deindustrialisation phase in which we are beginning to forget the traditional methods of production and are more involved in the service industry. By viewing traditional production processes, we nostalgically look upon our technical heritage and regain forgotten knowledge.

Since industrial tourism is a relatively less explored field of tourism, education in this area is particularly 
important. Organisations need to provide suitable and qualified personnel for implementing industrial tourism. Training at work and continuous improvements are particularly important for maintaining the competitiveness of the organisation (Salas \& CannonBowers, 2001; Rakowska, 2014; Bratton \& Gold, 2012). There are several essential points in performing industrial tourism that relate to the skills and knowledge of employees. First, as stated by Otgaar et al. (2010), there are numerous contact points of employees with visitors. The company must provide an appropriate and qualified guide that will lead the group around the company and present the operation of the organisation (Marsh, 2008). Furthermore, the company must also arrange the contact points of visitors with employees within the regular working process. In doing so, viewing should not interfere with the work process, and employees should not feel pressured by the visitors (Otgaar, 2010). There are also positive effects of such tourist visits, since employees are much more motivated, productive, and proud of their work in the presence of the public.

\section{Human Resources and the Tourism Sector}

Employees are one of the basic pillars of the organisation, since the success and the survival of it depends on their performance. This is particularly so in the tourism sector, which is a service activity and is based on the interaction of employees with tourists (Madera et al., 2017). Employees are defined as human resources or people who in any form participate in an organised form of human work and, therefore, work in an economic, political, sports, or similar organisation (Florjančič et al., 2004). They are also presented as work force that can be regarded as macro-meso-micro conceptualisations of the tourism workforce phenomena (Baum et al., 2016). Employees are the most essential element of each organisation, and they are involved in the process of achieving a group or individual goals (Bratton \& Gold, 2012).

Thus, employees represent the human capital of the organisation deriving from their knowledge and experience, education, professional competence, psychometric features, personality characters and abilities, entrepreneurial enthusiasm, innovation and creativ- ity, satisfaction, ability to adapt to changes, and similar (Moustaghfir, 2014; Armstrong, 2012). Human capital creates the value of an organisation and, therefore, it is necessary to manage it strategically. Moreover, recent studies emphasise that sustainable human resource management (Baum et al., 2016; Baum, 2019; Robinson et al., 2019) will replace strategic human resource management. Thus, a higher level of quality and practices that are responsible toward the environment, local society, culture, and economy should be also introduced in human resources management. This includes justice and equality, transparent $\mathrm{HR}$ practices, profitability, and employee well-being (Wikhamn, 2019).

Mihalič (2006) summarises Ulrich, stating that human capital management represents overall education and training of employees, developing their skills for them to contribute to the goals and needs of the company in which they work, and create added value. Similarly, Nickson (2013) states that successful human resources management leads to the organisation's success via appropriate recruiting, introducing new employees to their work, education and training, rewarding, and motivating employees. Human resources development takes place through the education and training processes, which represent the acquisition of new skills through various training programmes, courses and workshops (Heery \& Noon, 2008; Wilton, 2016). This is particularly important in the tourism sector, in which employees have constant contact with customers and are continuously under the tourist gaze (Urry \& Larsen, 2012) of their customers. In the case of industrial tourism, employees in production organisations also become visible. The most visible to visitors are the factory tour guides, which are representatives of the organisation. They must represent organisational values (Gorenak, 2019) and the organisation itself at its best with their knowledge, behaviour, and attitude. However, this requires proper education and training.

\section{Education and Training of Tourism Personnel}

The process of permanent education within the organisation can be defined as a network of events and activities for the development of the person's distinct abilities (Florjančič et al., 2004). We can also use the 
term 'training' for a systematic and planned preparation of the learning process, acquiring the knowledge and skills necessary to achieve the goals of the organisation (Boštjančič, 2011). Nickson (2013) defines training as activities with a focus on immediately improving employee performance by developing certain skills, acquiring knowledge and competences. Nickson (2013) also states that organisations in the tourism and transport sectors allocate the most resources for education and training to improve customer service and at the same time follow strict legal regulations on safety, health and nutrition standards. Another reason is the high rate of employee turnover, which requires the organisations to continuously educate new and inexperienced staff.

According to Mihalič (2006) and Bratton and Gold (2012), the goal of education and training is to increase the competency of employees for the work they do, and consequently increase their efficiency and effectiveness at work. In doing so, employees effectively develop their ability to adapt quickly and respond to changes that have occurred and to learn for the contemporary and future increasingly turbulent environment of modern organisations (Wojtczuk-Turek \& Turek, 2015). This promotes innovation, productivity, and employee satisfaction, their affiliation to the organisation, personal career development, the promotion of individuals and the organisation as a whole. All of this is also essential in the tourism sector, which requires educated, well-trained, intelligent, energetic employees with entrepreneurship skills and knowledge of several foreign languages in order to provide high-quality customer service, and hence efficiency and profitability of the tourist services (Gupta, 2011).

The acquisition of knowledge can be divided into external (implemented outside the organisation) and internal (implemented within the organisation) (Mihalič, 2006), but we can also define formal and informal acquisition of knowledge. Formal education and training of workers usually takes place outside the workplace (Florjančič \& Vukovič, 1999), is preplanned and structured. Informal acquisition of knowledge takes place in the form of information exchange, mutual assistance and joint problem solving (Frazis et al. in Rozman \& Kovač, 2012). Methods and forms of acquiring knowledge are highly diverse: lectures, discussions, demonstrations, conferences, case studies, teamwork, role-playing (simulation), computerassisted learning (CAI), simulations, manager games, e-learning, video lectures, courses, seminars, workshops, symposiums, meetings, and consultations (Florjančič et al., 2004; Mihalič, 2006). However, organisations are currently increasingly less inclined to use classical education methods. Modern forms of knowledge acquisition, such as e-learning, coaching, mentoring, simulation learning, job shadowing, rotational education, independent learning and other similar forms of new employee training methods are increasingly in use (Marchington \& Wilkinson, 2013). Research shows that advanced foreign organisations use only ten per cent of classical forms of acquiring knowledge to educate their employees (Mihalič, 2006). As Bhattacharya and Cohen (2017) write, English-language literature indicates the characteristics of a worker that can be acquired through learning with the abbreviation Ks A: knowledge - skills - abilities/attitudes. Likewise, we can label all of these characteristics as an employee's competence. We follow the definition of competences as a pool of knowledge, abilities, skills, experiences and values of the individual collected during education and career (Gorenak, 2013).

\section{Competences}

Competences have been studied and defined by several authors. The beginnings of the use of this term date back to the early 1970s, when David McClelland introduced the concept to improve the process of selecting personnel (Thanopoulos et al., 2011; Brophy \& Kiely, 2002; Gelhard, 2017). McClelland has identified competences as knowledge, skills, traits, attitudes, self-concepts, values or motives directly related to job performance or critical life outcomes and shown to differentiate between superior and average performers (Thanopoulos et al., 2011). Svetlik (2005) proposes a definition according to which competences are defined as the ability of the individual to activate, use, and connect the acquired knowledge in complex, diverse, and unpredictable situations. Rozman and Kovač (2012), Jauhari (2006), Kohont (2005) and others also cite similar definitions. 
The literature presents several approaches to the concept of competences. Competences are considered to be an individual's capacity, as an organisation's ability, and as a tool for better communication between the education system and the labour market (Kalargyrou \& Woods, 2011; Fominiene et al., 2015). In human resources, competences are used primarily to describe employees and estimate their ability to perform professional duties in different situations; according to employee competence, we can distinguish between average and above average employees; organisations can better achieve their strategic goals when recruiting employees with appropriate competences (Judrups et al., 2015).

To recognise the capabilities of employees more efficiently, competence models were designed. Swiderski (1987 in Thanopoulos et al., 2011) proposed three basic clusters: hard, soft, and conceptual competences. The first one includes technical and administrative skills; soft competences are also known as interpersonal skills, which include sensitivity, adaptability, creativity and flexibility; conceptual competences can be defined as critical thinking, problem-solving, judgment and decision-making.

In contrast, Spencer and Spencer (in Thanopoulos et al., 2011) distinguished two categories of competences. The first are threshold competences (like writing skills) that every employee must have; they are not exceptional behaviour. The second are differentiating competences (like decision-making ability) that show the difference between an average and extremely successful individuals.

Mihalič (2006) divided the basic competences into three sets. The first set are personal and behavioural competences (decision-making ability, strategic thinking, ethics, the ability of analytical and creative thinking and expression). The second set is the competence to work with people (the ability of interpersonal communication, public speaking, delegating, conflict management, negotiation, teamwork). The third section covers competences for working with information (project management ability, knowledge of business processes, sense of space, accuracy and promptness).

Regarding competences, one of the most important factors is that the organisation determines the basic competences that are crucial for all employees and the additional competences that employees need in certain positions or departments of the organisation (Moustaghfir, 2014; Stevens, 2012; Westeren, 2017). In the tourism sector, high-quality staff is of key importance, as tourism is a service activity that largely depends on the capable and hospitable employees (Gupta, 2011; Nickson, 2013). Gorenak and Gorenak (2012) analysed the competences needed by tour guides while performing a guided tour. There are different requirements among the European countries, since some emphasise theoretical knowledge of history and geography while others emphasise communication skills, managerial skills, foreign language knowledge, planning and problem-solving skills. As the basic competence of tourist guides, they cite excellence in tour-guiding techniques and communication competences. Fominiene et al. (2015) also confirm that the developed personality characteristics and interpersonal communication are the most important competences in the tourism sector.

Therefore, soft skills (hospitality, kindness, compassion) are far more important than hard or technical skills (knowledge of information technology), and this is reflected in the tourism industry. Employers state that their employees must not only know their professional field and theoretical content perfectly, but also have to respect themselves and others, be independent, responsible for their activities and end-results, be innovative, adaptable, be team-players, be able to communicate, participate, think critically and constantly set new goals.

Baum (2015) suggests that changes in the world contribute to shifts in the workforce skills demands while employers move their focus from technical skills to soft skills, for example. social media management knowledge, a wider portfolio of language, cultural and green skills. Moreover, employees must have a broad skillset; thus, they can perform a flexible range of tasks. Therefore, to enhance this skill set, training is vital.

\section{The Aims and Purpose of the Research and Research Questions}

As we wrote in the literature review, employees are a key element of the organisation's performance. This is 
particularly true in the tourism sector, which is a service activity and, as such, is even more dependent on the employees themselves: on their knowledge, skills, character, characteristics and also on their current well-being. Several research studies have already addressed various groups of tourism professionals, such as managers and tourist guides. However, we were interested in the state of industrial tourism employees. Industrial tourism is a relatively less explored area of tourism; at the same time, it is a mix of tourist services and factory production processes. Regarding this feature, we wanted to explore who is performing industrial tourism (or who is guiding factory tours), what competences are required for this work, and how they gain necessary knowledge. Considering that there is not a large number of organisations in Slovenia that allow visitors to view their production processes, we decided to focus the study on individual cases of production factory tours. We have designed the following research questions:

RQ1 Who performs industrial tourism in organisations (organisation employees or is industrial tourism arranged by outsourcing another organisation)?

$R Q 2$ What are the responsibilities of industrial tourism employees (is this their basic job or do they have other tasks)?

RQ3 Which competences and what knowledge should the industrial tourism employees have?

RQ4 How is the organisation concerned with knowledge management of industrial tourism employees (do they arrange training)?

\section{Methods Used}

After reviewing the existing literature in the fields of human resources and industrial tourism, observation with participation in the process of viewing the production process itself was used as a method of research. We decided to visit four Slovenian companies that offer factory tours, since industrial tourism in Slovenia is in the emerging stage and thus provides different case studies to examine. Our research sample was composed of four companies that advertise this product on their web sites and are among large companies in the country. The tours were held on 24 April 2018 at the location of Revoz (Renault automobile production), Novo mesto; on 21 May 2018 at the location of Pivovarna Laško Union (Union Brewery), Ljubljana; on 26 May 2018 at the location of Pivovarna Laško Union (Laško Brewery), Laško; and on 1 June 2018 at the location of the company Droga Kolinska, Food Industry (production of Argeta pâté), Izola. We told companies that we would take part in the factory tour, but to ensure greater credibility of the tour performance, we always joined a group that was already on the schedule. This was not possible at Revoz, because the company was in the confidentiality phase, and visits were not possible, except in specific circumstances. However, the tour of Revoz took place just as if a random group of visitors had attended it. During and after the end of the visits, we made notes about the delivery of the tour and double-checked the information at the end with the tour guide.

As a method of data acquisition, we also used a semi-structured interview with representatives of the departments responsible for industrial tourism planning (see list of informants in Table 1). At Revoz, we interviewed a representative of the Communication and Public Affairs Department; at Pivovarna Laško Union, we interviewed the head of the Corporate Events Department and the Union Experience (this person is responsible for industrial tourism in both visited breweries); at Droga Kolinska, the questions were answered by the head of production and by the marketing department. The basic questions were sent to the companies' representatives first via e-mail; they also answered additional questions after the factory tour was conducted. If factory tours were performed by another person and not by the company's industrial tourism representative, we also asked tour guides some of the same questions and obtained their answers.

\section{Findings}

We have found that each company has a different personnel policy in the implementation of industrial tourism. Thus, we can identify four types of industrial tourism human resources from our studied cases:

1. Staff, employed for the sole purpose of implementing industrial tourism. 
Table 1 List of Study Informants

\begin{tabular}{|c|c|c|c|}
\hline Respondent & Company & Department in the Company & Work tasks in industrial tourism \\
\hline Respondent A & Revoz & $\begin{array}{l}\text { Communication and Public Affairs De- } \\
\text { partment }\end{array}$ & $\begin{array}{l}\text { Strategic planning, reservations, visitor } \\
\text { communication, tour guiding, presenting. }\end{array}$ \\
\hline Respondent B & Pivovarna Union & $\begin{array}{l}\text { Corporate Events Department and the } \\
\text { Union Experience }\end{array}$ & Strategic planning, recruiting tour guides. \\
\hline Respondent C & Pivovarna Laško & Corporate Events Department & $\begin{array}{l}\text { Strategic planning, communication with } \\
\text { outsourcing organisation. }\end{array}$ \\
\hline Respondent D & Droga Kolinska & Marketing department; Production & $\begin{array}{l}\text { Strategic planning, scheduling production } \\
\text { workers for guiding tours. }\end{array}$ \\
\hline
\end{tabular}

2. Staff, employed in Communications, PR, Marketing, and similar departments.

3. Staff, employed in the production process.

4. Staff from outsourcing organisations.

The workplace of the first type of industrial tourism employees is the post of industrial tourism operator. This means that people are employed as hosts who take care of regular factory tours, visitor programmes, and presentation of the company. In the case of Pivovarna Laško Union, this type of employees can be found at the Union Brewery in Ljubljana. Their hosts are students or people on working contracts. Nevertheless, these employees have no influence on the content of the factory tour or on the strategic decisions regarding industrial tourism. The decision-makers in this process are the management of the corporate relations department and the company's management itself. The workplace of the second type of industrial tourism employees is in the department for communication, public relations, marketing and similar. Such an example can be found at the automotive company Revoz in Novo Mesto, where the representative of the Communications and Public Affairs Department conducts factory visits, represents the company and is in contact with visitors. The reasons that this is under their department are given by Respondent A:

We used to have a network of tour guides who were experts from the production departments. But it turned out that visitors were not interested in technical details as in an interesting and fun presentation itself. So, we made the decision to hand over tour guiding to the communication department. Why? As a department, we are constantly near information, factory innovations, and we have excellent communication skills.

Their work also includes planning and strategic insight into the implementation of industrial tourism and, as such, are also responsible for the future development of this kind of service. Nevertheless, the company's management confirms the final strategic decisions.

As a third type of industrial tourism employees, a person who is employed in production can carry out industrial tourism. An example is the production of Argeta pâté plant in Izola, Droga Kolinska Company. There, the visitors are welcomed by a person, employed as a technologist in production, which is, in fact, the position of the company's production process. Respondent D explained the process of selecting tour guides.

Factory tours are guided by those employees, who know the production process and speak the language of the visitors. Usually, this is done by the head of production, but we also make daily agreements who gets to guide which tour, since this is related to our ongoing activities that we perform besides factory tour guiding.

This person pauses his/her professional obligations 
at the time of carrying out the factory tour, takes over the group, takes it through the production premises, and presents the company and the production process. In doing so, he/she can use his/her expertise, which he/she uses in everyday work. However, this person does not participate in the strategic planning of the development of industrial tourism. For this, the heads of production and marketing department are responsible.

The last type is cooperation with external organisations who carry out factory tours. This form of outsourcing can be found in the company Pivovarna Laško Union, more precisely in the brewery in Laško. There, employees of the public institution 'Centre for Sport, Tourism, Information and Culture Laško' (Center za šport, turizem, informiranje in kulturo Laško s тік) carry out the factory tours. Their tasks include contacting and guiding visitor groups, presenting the company and its production processes. They are in contact with the company Pivovarna Laško Union, but do not influence the strategic decisions regarding the implementation of industrial tourism. The decisionmakers in this process are the management of the corporate relations department and the company's management itself. After the interviews, we could see companies' need for different employees' competences. Thus, in the Union brewery, where we detected the first type of industrial tourism human resources, they highlight competences, such as the expert knowledge of the factory history and the process of brewing beer. In addition, the guides need to have good communication skills and a good sense for people. For visitor groups, requiring specific knowledge of production processes, production employees, who can provide more detailed information on professional issues, are recruited as tour guides.

Most of the groups are guided by our presenters; these are students or contract workers. When hosting specific groups (Biotechnical Faculty, Mechanical Engineering Faculty, Biotechnical educational centre, ...) I ask for help from other production employees, like engineer officers, energetics expert, microbiologists or food science experts. [Respondent B]
It is also desirable for a factory tour guide to be inventive and adjustable to the group needs in order to choose an appropriate way of guiding. For example, it is possible to select only an oral representation of the factory or visitors can participate in a treasure hunt where information is thus conveyed in a fun manner. In doing so, the guide must have the skills to perform the playful treasure hunt. The knowledge of foreign languages (Slovene, English, Croatian) is also important.

The second type of industrial tourism human resources, carried out by Revoz, highlights the importance of knowing the production process, the knowledge and use of IC T (PowerPoint, video, headphones), the time availability of the guide and his/hers tour guiding experience. Since the guide is responsible for the whole process from booking to guiding, he/she must also master communication skills, know how to make a system announcement, check the operation of ICT and security equipment, know the procedures for arranging a possible catering offer for certain visitors, and personally engage in the performance of the tour itself. Furthermore, since the guide is also responsible for the development of industrial tourism, it is expected that he/she also has the skills of strategic planning, is creative, and takes initiative. As the most important element, they point out that a person who carries out factory tours must have good communication skills, as well as sense for people in order to judge what a particular group is more or less interested in, so that the guide can adjust explanations accordingly (e.g., students compared to business partners).

Moreover, he/she has to know the production process, be aware of the innovations in production, and be widely educated. If there is a group that requires more specific knowledge of the company, one of the production employees also joins the tour and gives more detailed information. The factory set up this system after production employees first performed the tours, but it turned out that visitors were not interested in many technical details. They much more prefer an interesting and attractive interpretation of a tour guide with excellent communication skills.

In the case of industrial tourism in the production of Argeta pâté, where we detected the third type of 
industrial tourism human resources; important competences are knowledge of the production process, safety and sanitary rules, knowledge of the visitor's language and time availability of the guide with regard to his/hers other duties.

The fourth type of industrial tourism human resources was found in the Laško brewery. The guides must have guiding expertise and especially good communication skills, according to Respondent C:

Groups that STıK brings to the Laško Brewery are guided by their tour guides, who are trained for the job. In addition to expert knowledge about the production process, they have to have foremost a good sense for communication with people.

For groups requiring specific information about the production processes, they invite additional production employees (e.g., technicians) to provide more detailed information on professional issues. Since the factory is located near a health resort and a spa, hosting tourists from different countries, knowledge of foreign languages, such as Italian, English, Spanish, German, and Serbian, is also essential. They also point out the flexibility of the guide to the situation and to the group needs, as well as the guide's administrative skills needed to carry out visits booking and collect entry fees.

Companies also take care of the knowledge development of their industrial tourism employees. In the Union brewery, training is carried out at the annual level or, if necessary, each time there is something new in the production process. The new guides are introduced to industrial tourism in such a way that they firstly attend a factory tour as visitors, when someone else guides a tour. Further, it is recommended to use 'job shadowing' and monitor experienced employees at the workplace. Then they receive a text with the information data that they have to learn for their presentation. Prior to their first officially executed tour, they conduct an internal factory tour for their co-workers to check their knowledge and skills. In addition, guides also conduct $\mathrm{HACCP}$ training and practice their skills of how to pour a beer correctly. Guides hold regular meetings on current affairs, occasionally attend various training courses, such as psychological lectures on people skills, training on gamification, branding, and similar.

Revoz does not organise special training for guides. Before new guides begin with the factory tours, they can study a guidebook with the main information about the company and the factory tour process. They used to have regular meetings with tour guides, but since guiding has been taken over by the communication department, there are no more such meetings, as there are not many people involved in the process.

We don't have trainings for factory tour guides. In the past, we used to have regular meetings with tour guides, when there was still a network of tour guides. But since communication department took that over, that is gone. [Respon$\operatorname{dent} \mathrm{A}]$

For guides who are conducting the tour of Argeta pâté production, the company does not carry out training or has no introduction lessons. There are only regular short coordination meetings about the division of groups among different guides and other special arrangements. In contrast, the Laško brewery provides annual training sessions for their tour guides and especially when there is something new in the production process. Furthermore, the guides coming from s TIK must take part in the training for local tourist guides; before they start conducting factory tours, they study literature about the brewery, so they can learn as much about the factory and the production process as they can.

\section{Discussion}

Companies use different types of industrial tourism human resources, which is mainly dependent on the availability of personnel and the degree of importance that industrial tourism has for the company itself. Regarding staff availability, the most basic type of industrial tourism human resources could be identified as employees working only for the purpose of implementing factory tours, as the staff is most easily accessible. 
The importance of industrial tourism is reflected in the significance of this offer for the company. The product is most important in companies for which the supply of industrial tourism is considered as a selfcontained product, and is not just a marketing tool but can become a self-standing tourist attraction of the destination. Thus, in the Union brewery, they offer a unique experience product, 'Union Experience, for which they employ staff solely for implementing industrial tourism. Since the product is regularly accessible to visitors, there is also a need for a greater number of employees. In addition, the product is designed and adjusted to different groups of visitors; thus, employees should consider this characteristic while preparing for a factory tour. This type of human resources seems to be most appropriate, since employees best know their work tasks; they specialise in group tours and develop all the necessary competences for conducting industrial tourism. However, in the case of this company, tour guides do not participate in the strategic planning of industrial tourism: they are only service providers. Here, the company should consider how to incorporate guides into strategic planning, since they know both the situation in the production areas and the characteristics, needs, and wishes of the visitors with whom they are talking during the tours.

For the other three types of industrial tourism human resources, employees' time is much less available, since their basic tasks are in other areas, or they are not employed at the factory and thus are not permanently present. The importance of industrial tourism is reflected in the strategic plans for industrial tourism and employee involvement in these decisions. This was the highest in the case of Revoz, where the tour guide also develops the product of industrial tourism itself, as the company wants to develop a factory tour as a selfcontained product in the future.

As we have found in the study, the competences of industrial tourism employees are critical. Among them, the most outstanding is the knowledge of the production process itself that all companies require from their tour guides. Communication skills, foreign language skills, and flexibility were also common responses, which means that companies expect their employees to master soft and hard skills (according to
Swiderski, 1987 in Thanopoulos et al., 2011) or competences for working with people and for working with information (according to Mihalič, 2006). In one company (Revoz), the employee is also responsible for the development of industrial tourism, so that personality and behavioural competences are also expected (according to Mihalič, 2006), which shows that the employee is capable of decision-making, strategic thinking, analytical and creative thinking. According to these findings, companies that offer industrial tourism can search for potential employees who already have communication skills, speak foreign languages, and are willing to learn about the company itself and the production process. Since we suggest that guides are also involved in the strategic development of the product, potential employees may also have characteristics of creativity, planning skills, and the like.

While the desired competences of employees in all companies are similar, the situation is different when examining the field of knowledge development among companies. Basic training is mainly placed at the beginning of the work when an employee is introduced to industrial tourism. At that, either companies time carry out internal training or employees read the guidebooks on industrial tourism in the company. Later, only one company responded that employees also organise additional training in the areas of people skills, brand knowledge, gamification, and others. Two companies also prepare training for the introduction of new features production, which potentially influence the course and content of the factory tours.

It can be noted that companies that see industrial tourism as a stand-alone product are investing more in the development of the knowledge of industrial tourism employees. Thus, the Union's Union Experience is currently a stand-alone product: a tour of the Union brewery, for which guides are systematically educated about the production process and guiding skills while the company simultaneously takes care of the development of their soft competences. This could be followed by other companies that plan to introduce a self-contained tourist product. At the beginning, they would prepare the introduction courses for the new guides, prepare a guidebook with basic information, and instruct and train the employees in the field of soft 
skills, since they all stated that the ability to communicate is the most important. Hence, soft skills should be more emphasised in employee training. All of these findings are summarised in the model of industrial tourism personnel, which is presented in Figure 1.

As shown in the model, we start with proposed three sets of competences that employees in industrial tourism need. These include the necessary competences for working with people, for working with information, and for personal and managerial competences. According to the obtained data in the literature and the study, we propose three types of workplaces that deal with industrial tourism. They are an independent department for industrial tourism, industrial tourism as part of the marketing and PR department, and the participation of an outsourcing organisation.

The independent industrial tourism department consists of the head of the department and factory tour guides. The head is responsible for the development of the industrial tourism product, but he/she should also include guides in strategic decisions, although they have a more operational role to play. This form is used when the product of industrial tourism is already well developed.

In the second form, a factory tour guide is also a person who is responsible for the development of the product; that person is a member of another department, presumably marketing or public relations department. This form of industrial tourism workplace is used when the product of industrial tourism is in the development phase.

The third form of industrial tourism organisation is the outsourcing to an external organisation that provides guides for the factory tours and other assignments. Meanwhile, a person who takes care of the development of the industrial tourism product is a member of another department (presumably marketing or public relations). This form of industrial tourism organisation is used when the product is in the development stage, and there is a simultaneous lack of available company staff to conduct tours.

In all three cases, we propose a system of training for all personnel involved in industrial tourism. First, training should be prepared prior to the beginning of work, where more emphasis is placed on pro- fessional knowledge about the factory and about guiding techniques. Then, during the implementation of factory tours, a number of additional training sessions should be prepared annually, which focus on soft competences. Based on this model, the organisation can select the most suitable employees for the implementation of industrial tourism, place them to the appropriate workplace, and continuously care for the development of their knowledge.

\section{Conclusion and Implications}

In this study, we focused on industrial tourism and industrial tourism human resources. Regarding the situation in the four studied cases at the companies (Revoz, Pivovarna Laško Union (Union and Laško Brewery) and Droga Kolinska), we can summarise our findings and answer our research questions. In response to the first two research questions, four types of industrial tourism human resources can be identified: staff employed only for the purposes of industrial tourism; staff employed in the communication, PR, or another department; staff employed in core production process; staff outsourced from an external organisation. The first three types are represented by employees working in the parent organisation, while the latter type includes employees who primarily work outside the parent organisation. Employees duties include visitor guiding and presentation of the factory, while the other type of employees (employees coming from the communication or PR department) also strategically plan the product development. In other cases, strategic planning is a part of management tasks.

Further on, we were interested in which knowledge and competences industrial tourism employees should possess. Here we have found that the critical competences are, first of all, professional knowledge of the production process. Communication skills, foreign language skills, and flexibility were also common responses; hence, soft skills are also very important in industrial tourism as in other tourism workplaces (Fominiene et al., 2015; Baum, 2015). Such competences are required primarily with factory tour guides that are in direct contact with visitors. The guides embody the company and, therefore, they need to know accurate and interesting factory technical information and use 


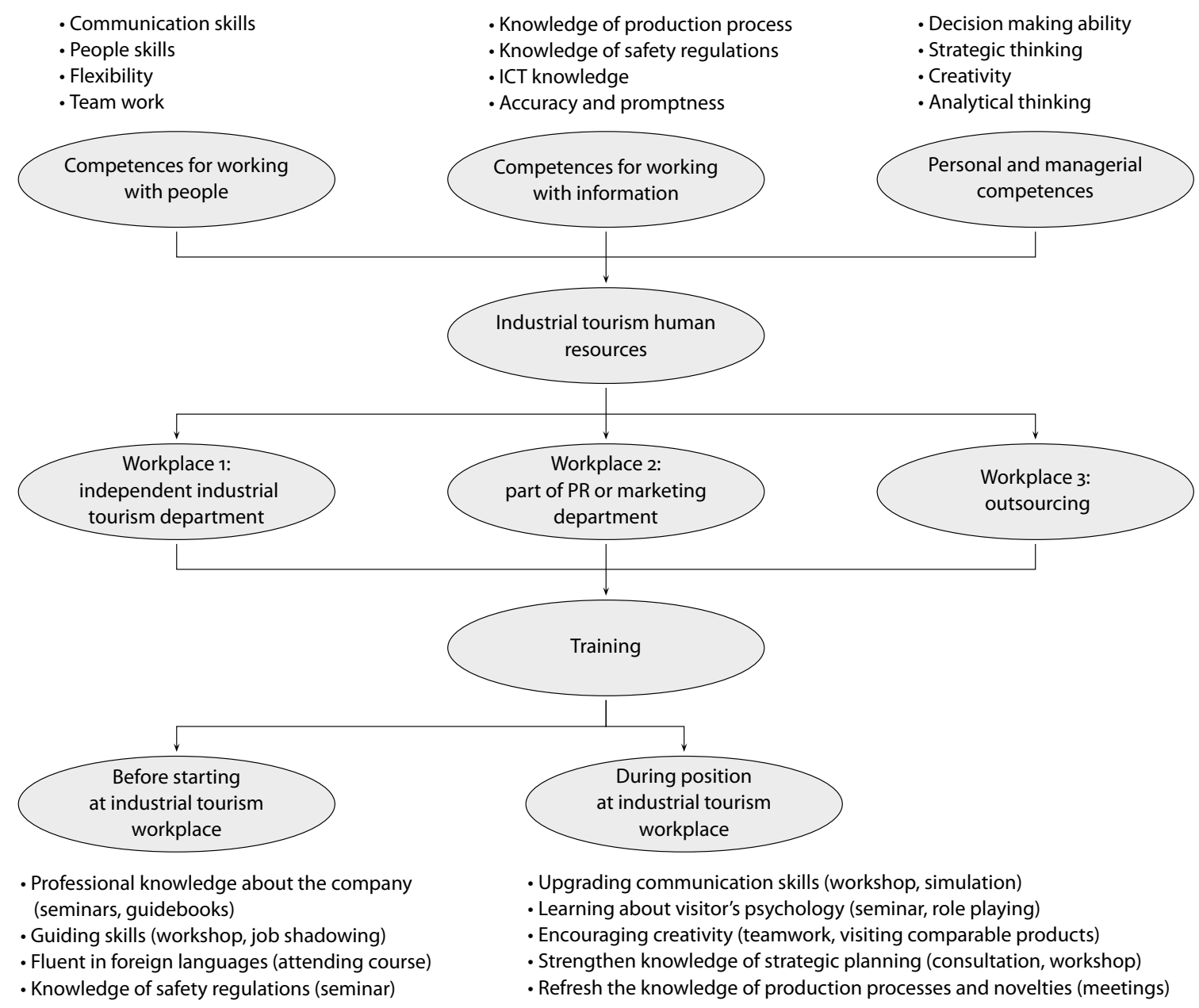

Figure 1 Industrial Tourism Human Resources

the correct way of presenting this information in order to attract the visitors.

All in all, one of the motives for the implementation of industrial tourism for the studied companies is marketing of their basic product, which is also done by the factory tour guide. In addition to the guide, industrial tourism also needs people who are strategically developing this tourism product. In one case, this person is also a guide; in other cases, this person is a part of management from marketing or PR department. Personnel at such positions also need the competence of strategic planning, analytical thinking, and creativity, which ensures that operational employees can provide quality industrial tourism services and strive for its continuous improvement, so that the product will be even more impressive for visitors and will represent the excellency of the visited company.

For employees to achieve basic competences, the final research question was addressed. The key finding is that studied companies provide a short list of required trainings. In companies that offer training, it is primarily placed at the beginning of an employee's job in industrial tourism, so he/she can acquire some expertise for the factory tour. This is done in the form of self-learning from a guidebook or with the help of experienced co-workers. Especially coaching and mentoring are among highly used new learning methods, which is characteristic of industrial tourism em- 
ployee training as well as for general employee training (Marchington \& Wilkinson, 2013). Insofar as industrial tourism has been developed as a stand-alone product of the company, the company offers more training possibilities, which are also aimed at the attainment of other competences not just professional knowledge of the factory. Thus, the guide can also be trained in communication skills and the psychology of visitors.

As shown in the literature review, studies about industrial tourism neglected this specific viewpoint; thus, research about human resources in industrial tourism brings new insight into the field. Based on the presented findings, we can propose that companies wishing to develop an independent industrial tourism product strategically plan for the staff they need for the implementation of it. They can follow the proposed model in Figure 1 and, according to the availability of employees, choose the most appropriate type of industrial tourism human resources. It is recommended that the guide, insofar as it is an independent workplace or an outsourced co-worker, will also be involved in the strategic planning of the development of this product, as it is he/she who daily encounters visitors and knows their needs and the situation of the premises where the tour occurs. By selecting a type of human resources, the company must also be aware of the competences it seeks for these employees.

Considering that, we recommend the involvement of guides in strategic decisions; the company should also look for personal and behavioural competences in guides in addition to the competences for working with people and the competences to work with information.

In any case, the company must provide constant employee training. Before starting their position in industrial tourism, employees must be equipped with professional knowledge of the company, knowledge of foreign languages and security provisions. Prior to starting work and during the course of work, the organisation must provide for the improvement of communication skills, people skills, as well as competences for encouraging creativity and knowledge of strategic planning. Therefore, the organisation should have a training plan for new and existing industrial tourism employees. When providing personal and knowledge development, the organisation will direct its focus towards sustainable human resource management and thus secure better working conditions for its employees.

The study has shown that there are quite a few differences between companies, as well as some similarities, based on which we revised the human resources in industrial tourism. The proposed industrial tourism human resources model could be used by organisations that want to improve their industrial tourism process or are only beginning to implement industrial tourism, thus choosing the type of human resources best suited to their situation and capabilities.

The research was conducted on the small sample of Slovenian companies that carry out industrial tourism. The sample itself is a considerable limitation of this research, since the number of factory visits should be higher to strengthen the results. In addition, multiple visits to each factory would provide greater insight into the process itself; however, due to the time limitation of the study, only one visit per factory was conducted. Nevertheless, we presume that the results are representative of the studied issue and provide a general picture of industrial tourism employees. Despite the fact that the situation is expected to be similar in other factories and countries, we propose that further research would be directed to companies abroad. In particular, the most important findings will be from the case studies of companies that have a long tradition of implementing industrial tourism and offer it as a stand-alone product. Furthermore, they can provide an environment for a more in-depth study of the industrial tourism employees not only focusing on their skills or training but also on their other characteristics, their background, the conditions in which they work, their performance, and service/experience delivery.

\section{References}

Armstrong, M. (2012). Armstrong's handbook of human resource management practice. Kogan Page.

Baum, T. (2015). Human resources in tourism: Still waiting for change? A 2015 reprise. Tourism Management, 5o(c), 204-212. 
Baum, T. (2019). Hospitality employment 2033: A backcasting perspective. International Journal of Hospitality Management, 76(Part B), 45-52.

Baum, T., Kralj, A, Robinson, R. N. S., \& Solnet, D. J. (2016). Tourism workforce research: A review, taxonomy and agenda. Annals of Tourism Research, 6o, 1-22.

Bhattacharya, S., \& Cohen, M. B. (2017). Tacit knowledge and intra-firm teams: Reaping the benefits of co-operation in a networked world. In M. Russ (Ed.), Human capital and assets in the networked world (pp. 151-173). Emerald.

Boros, L., Martyin, Z., \& Pal, V. (2013). Industrial tourism trends and opportunities. Forum geografic: Studii şi cercetări de geografie şi protecția mediului, 12(1), 108-114.

Boštjančič, E. (2011). Merjenje kompetenc: metoda ocenjevalnega centra $v$ teoriji in praksi. Planet GV.

Bratton, J., \& Gold, J. (2012). Human resource management: Theory and practice. Palgrave Macmillan.

Brophy, M., \& Kiely, T. (2002). Competences: A new sector. Journal of European Industrial Training, 26(2/3/4), 165176.

Chow, H.-W., Ling, G.-J., Yen, I.-Y., \& Hwang, K.-P. (2016). Building brand equity through industrial tourism. Asia Pacific Management Review, 22(2), 1-10.

Edelheim, J. R. (2015). Tourist attractions: From object to narrative. Channel View Publications.

Florjančič, J., \& Vukovič, G. (1999). Kadrovska funkcija management. Moderna organizacija.

Florjančič, J., Bernik, M., \& Novak, V. (2004). Kadrovski management. Moderna organizacija.

Fominiene, V. B., Mejeryte-Narkeviciene, K., \& WozniewiczDobrzynska, M. (2015). Employees' career competence for career success: Aspect of human resources management in tourism sector. Transformations in Business \& Economics, 14(2B/35B), 481-493.

Frank Orel, T., \& Medarić, Z. (2018). Cultural tourism froman academic perspective. Academica Turistica, 11(2), 101-110.

Frew, E. A. (200o). Industrial tourism: A conceptual and empirical analysis (Unpublished $\mathrm{PhD}$ dissertation). Victoria University.

Gelhard, A. (2017). Kritika kompetence. Krtina.

Goeldner, C. R., \& Ritchie, J. R. B. (2003). Tourism: Principles, practices, philosophies. Wiley.

Gorenak, M. (2013). Organizacijske vrednote in kompetence kot orodje za razvoj človeških virov. In V. Dermol (Ed.), Sodobni izzivi managementa človeških virov (pp. 11-23). Mednarodna fakulteta za družbene in poslovne študije.

Gorenak, M. (2019). The differences in perceptions of organ- isational values in the hospitality sector: What do they tell us? Academica Turistica, 12(1), 73-82.

Gorenak, M., \& Gorenak, I. (2012). Challenges in education of tour guides and tour managers. Informatologia, 45(4), 287-296.

Gržinić, J., Zanketić, P., \& Baćac, R. (2009). Industrial tourism in Istria. Ekonomska misao i praksa, 18(2), 211-232.

Gupta, B. (2011). Competences' importance and performance in tourism industry: An application of the importance performance analysis model. The International Journal of Interdisciplinary Social Sciences, 5(10), 117-133.

Heery, E., \& Noon, M. (2008). A dictionary of human resource management. Oxford University Press.

Holloway, J. C., \& Humphreys, C. (2016). The business of tourism. Pearson Education.

Ifko, S. (2010). Trendi razvoja industrijskega turizma v Evropi. In A. Brezovec, \& J. Mekinc (Eds.), Management, izobraževanje in turizem: družbena odgovornost za trajnostni razvoj: zbornik referatov 2. znanstvene konference $z$ mednarodno udeležbo (pp. 715-727). Fakulteta za turistične študije - Turistica.

Jauhari, V. (2006). Competences for a career in the hospitality industry: An Indian perspective. International Journal of Contemporary Hospitality Management, 18(2), 123134 .

Judrups, J., Zandbergs, U., \& Kazakovs, M. (2015). Competence based human resource development solution. In 14th International Scientific Conference Engineering for Rural Development (pp. 669-974). Latvia University of Agriculture.

Kajzar, P., \& Václavínková, K. (2016). Prerequisites adventure tourism in the Moravian region with a focus on rural and industrial tourism. In V. Klímová \& V. Žítek (Eds.), 19th International Colloquium on Regional Sciences, Conference Proceedings (pp. 1008-1015). Masarykova univerzita.

Kalargyrou, V., \& Woods, R. H. (2011). Wanted: Training competences for the twenty-first century. International Journal of Contemporary Hospitality Management, 23(3), $361-376$.

Kohont, A. (2005). Razvrščanje kompetenc. In M. S. Pezdirc (Ed.), Kompetence v kadrovski praksi (pp. 29-48). GV izobraževanje.

MacCannell, D. (2013). The tourist: A new theory of the leisure class. University of California Press.

Madera, J. M., Dawson, M., Guchait, P., \& Belarmino, A. M. (2017). Strategic human resources management research in hospitality and tourism. International Journal of Contemporary Hospitality Management, 29(1), 48-67. 
Marchington, M., \& Wilkinson, A. (2013). Human resource management at work. Chartered Institute of Personnel and Development.

Marsh, A. C. (2008). The ultimate vacation: Watching other people work, a history of factory tours in America, 18801950 (Unpublished PhD dissertation). Johns Hopkins University.

Mihalič, R. (2006). Management človeškega kapitala. Mihalič in Partner.

Moustaghfir, K. (2014). Strategic human resource management: An HR planning toolkit. In V. Dermol \& A. Rakowska (Eds.), Strategic approaches to human resources management practice (pp. 27-51). ToKnowPress.

Nickson, D. (2013). Human resource management for the hospitality and tourism industries. Routledge.

Otgaar, A. H. J. (2010). Industrial tourism: Where the public meets the private (Unpublished $\mathrm{PhD}$ dissertation). Erasmus University Rotterdam.

Otgaar, A. H. J. (2012). Towards a common agenda for the development of industrial tourism. Tourism Management Perspectives, 4, 86-91.

Otgaar, A. H. J., Van den Berg, L., Berger, C., \& Xiang Feng, R. (2010). Industrial tourism: Opportunities for city and enterprise. Ashgate Publishing.

Page, S. J., \& Connell, J. (2014). Tourism: A modern synthesis. Cengage Learning.

Rakowska, A. (2014). Managing diverse human potential: Challenges or benefits for organizations? In V. Dermol \& A. Rakowska (Eds.), Strategic approaches to human resources management practice (pp. 9-25). ToKnowPress.

Robinson, R. N. S., Martins, A., Solnet, D., \& Baum, T. (2019). Sustaining precarity: Critically examining tourism and employment. Journal of Sustainable Tourism, 27(7), 1008-1025.

Rodríguez-Zulaica, A. (2017). Redefiniendo el concepto de Turismo Industrial: Comparativa de la terminología en la literatura castellana, francesa y anglosajona. Revista de Turismo y Patrimonio Cultural, 15(2), 311-318.
Rozman, R., \& Kovač, J. (2012). Management. GV založba.

Salas, E., \& Cannon-Bowers, J. A. (2001). The science of training: A decade of progress. Annual Review of Psychology, 52(1), 471-499.

Svetlik, I. (2005). O kompetencah. In M. S. Pezdirc (Ed.), Kompetence $v$ kadrovski praksi (pp. 11-27). GV izobraževanje.

Thanopoulos, C., Manouselis, N., \& Stracke, C. M. (2011). Understanding and adaptation of the concept of competences in the water sector. Agris On-Line Papers in Economics \& Informatics, 3(1), 67-86.

Urry, J., \& Larsen, J. (2012). The tourist gaze 3.o. Sage.

Vargas-Sánchez, A., Porras-Bueno, N., \& Plaza-Mejía, M. Á. (2014). Industrial tourism. In J. Jafari \& H. Xiao (Eds.), Encyclopedia of tourism (pp. 470-472). Springer.

Westeren, K. I. (2017). Knowledge transfer networks, value creation, and cultural aspects of industrial production. In M. Russ (Ed.), Human capital and assets in the networked world (pp. 3-18). Emerald.

Wikhamn, W. (2019). Innovation, sustainable HRM and customer satisfaction. International Journal of Hospitality Management, 76(Part A), 102-110.

Wilton, N. (2016). An introduction to human resource management. Sage.

Wojtczuk-Turek, A., \& Turek, D. (2015). Diversity-oriented competences: A major challenge for human resources development. In A. Rakowska \& K. Babnik (Eds.), Human resources management challenges: Learning \& development (pp. 31-62). ToKnowPress.

Xie, P. F. (2006). Developing industrial heritage tourism: A case study of the proposed jeep museum in Toledo, Ohio. Tourism Management, 27(6), 1321-1330.

Yamashita, S. (2014). Cultural tourism. In J. Jafari \& H. Xiao (Eds.), Encyclopedia of tourism (pp. 2012-2014). Cham. 